\title{
Konservatuvarlardaki Obua Eğitiminde Kamış Yapımının Müfredata Dahil Edilmesi Gerekliliğï
}

\author{
Necessity of Introducing Courses on Reedmaking in Oboe \\ Education in Conservatories
}

\author{
Ayşe SEZER ${ }^{2}$ (1)
}

DOI: 10.26650/CONS2019-0001

Bu makalede yer alan sonuçların bir kısmı 3-5 Mayıs 2018 tarihlerinde Alanya Alâeddin Keykubat Üniversitesi'nde gerçekleşen 4. Uluslararası Güzel Sanatlar Sempozyumu'nda sözlü bildiri olarak sunulmuștur.

${ }^{1}$ Akdeniz Üniversitesi, Antalya Devlet Konservatuvarı, Antalya, Türkiye

ORCID: A.S. 0000-0002-6494-6001

\section{Sorumlu yazar/Corresponding author: Ayşe Sezer, \\ Akdeniz Üniversitesi, Antalya Devlet Konservatuvarı, Antalya, Türkiye \\ E-posta/E-mail: aysesezer@akdeniz.edu.tr}

Başvuru/Submitted: 18.02 .2019

Revizyon Talebi/Revision Requested: 31.05.2019

Son Revizyon/Last Revision Received: 18.06.2019

Kabul/Accepted: 24.06 .2019

Online Yayın/Published Online: 11.06 .2019

Atıf/Citation: Sezer, A. (2019).

Konservatuvarlardaki obua eğitiminde kamış yapımının müfredata dahil edilmesi gerekliliği. Konservatoryum - Conservatorium, 6(1), 47-63. https://doi.org/10.26650/CONS2019-0001

\section{ÖZ}

Obua kamışla çalınan tahta üflemeli bir enstrümandır ve kamış ton kalitesini belirleyen en önemli faktördür. Kamışın hammaddesi olan kargı, makine ve alet kullanımıyla şekillendirilerek çalınmaya hazır hale getirilir. Ton anlayışına uygun ve iyi sonuç veren bir kamış yapabilmek uzun bir eğitim süreci gerektirir. Kullanılan malzemeler ve el alışkanlığı kazanmak gerekliliği de düşünüldüğünde, kamış yapımını öğrenmek için gereken süre ve emek, iyi seviyede obua çalabilecek duruma gelebilmek için gereken ile hemen hemen aynıdır. Obua kamışı yapımı ve pedagojisi adı altında birçok kaynak bulunmaktadır. Ancak, kamış yapımının hangi yöntemlerle ve nasıl öğretilmesi gerektiği ile ilgili yol gösterici bir kaynağa rastlanmamıştır. Bu çalışmada, Yükseköğretim Kurulu Başkanlığı Tez Merkezi ve Proquest veri tabanında obua kamışı, kamış yapımı ve kamış eğitimi ile ilgili tezler incelenmiş, elde edilen 15 tez çalışmanın örneklemini oluşturmuştur. Yapılan inceleme sonucunda, pek çok obua eğitimcisinin kamış yapımının önemine değinmesine rağmen, kamış yapımı eğitiminin müzik okullarındaki müfredata dahil edilmediği tespit edilmiştir. Araştırma süresince incelenen tezler, bu alanda eğitmenlerin başvurabileceği yeterli kaynağın olmadığını ve kamış yapımı eğitiminin belli bir müfredata ve sürece dayanmadığını destekler niteliktedir. Çalışmanın literatürde bu alandaki boşluğa katkıda bulunması, kamış yapımı eğitiminin önemine dikkat çekmesi ve diğer çalışmaları tetiklemesi hedeflenmiştir.

Anahtar Kelimeler: Obua, Obua Kamışı, Kamış Yapımı Eğitimi

\section{ABSTRACT}

Oboe is a double-reed woodwind instrument and the reed is the most crucial factor that determines the tone quality. The reed is made of a material that is known as "kargı" in Turkish. It takes many hours of delicate effort and skillful use of various tools to put the material in a form that an artist can play. Despite the significance of reedmaking learning in overall oboe education, there are not many studies on reedmaking pedagogy. In this study, I examine the previous dissertations on oboe reed, reedmaking and its education in Turkish Higher Education Council Thesis Center and Proquest database. I have sampled 15 dissertations from the resources. I have observed that although many oboe educationists acknowledge the crucial importance of reedmaking, reedmaking education is not a part of the curriculum in music schools. There is a lack of literature and textbooks that educationists can refer to in this area whereas there is a strong need for a formal and generic curriculum in oboe reed education. My work is an attempt to help fill the gap in the literature, aims to draw attention to reedmaking education and initiate further studies in the field. Keywords: Oboe, Oboereed, Reedmaking Education 


\section{EXTENDED ABSTRACT}

Reedmaking is at the center of teaching and performing aspects of oboists' skills as other critical matters in the profession. It is a complicated process and education to obtain a reed that fits well to the artist's tone preferences. We cannot overestimate the impact of the quality of the reed on the performance of the player. It is a fairly difficult task to produce one. When it comes to reedmaking there are many factors that are considered: The texture of the reed is easily affected by the physical conditions of the air in the setting, one needs a reed that is a good fit for the performer's mouth and teeth and that suits well to the desired tone. Because of the various number of parameters, one can often fail to obtain a reed of the same quality even after applying the exact same procedures. Given this complexity, to master this reedmaking one needs to commit just as much to learn how to play it with skill. It is a crucial part of oboe education that a student has the skills to produce a reed in accordance with the tone preferences and the position of the mouth.

Despite the significance of reedmaking learning in overall oboe education, there are not many studies on reedmaking pedagogy.

In this study, I examine the previous dissertations on oboe reed, oboe reedmaking and its education in Turkish Higher Education Council Thesis Center and Proquest database. I have sampled 15 dissertations from these sources. A search based on the keyword oboe through Turkish Higher Education Council Thesis Center yielded 16 theses and only 3 of them mentioned oboe- reedmaking and its significance. In the Proquest database, they are 220 theses classified under the titles oboe, oboe reed and reedmaking and only 12 mentioned reed making.

In these studies, it is set as an eventual goal that oboists should be able to make their own reed and until then it is considered to be their teachers' responsibility to provide reeds that students need. In these sources, reed is given the due credit for its effect on the performance and some techniques of reed making are reviewed. In one study, it is looked at how and with what means reedmaking is thought in schools.

It is concluded that there is no method on the pedagogy of reedmaking that would help teachers with learning strategies and levels of learning outcomes in this area. Reedmaking is not a part of the curriculum in music schools. Furthermore, there is no proposed method for reedmaking education in the literature. It should be noted that there are many 
different styles in reedmaking and reedmaking education and there is no unique way to make a good reed. The sources that are available now focus more on the technical details of reedmaking and overlook the pedagogical aspects of the education. Reedmaking education methods are not unified and vary greatly among teachers, students, and institutions.

As a conclusion, I propose that a reedmaking course should be a part of the curriculum and a unified education method should be developed in reedmaking. It is the teachers' responsibility to describe how to make a reed and make the student capable in making a reed that can be played comfortably and can produce sounds that fit well to the tone preferences and the mouth position. Especially in our country, in every school where oboe is taught reedmaking should also be taught and this should be done in a systematic way through a well-planned curriculum. To this end, a method book can be realized that would serve as a textbook. My work is an attempt to help fill the gap in the literature and I hope that it will stimulate more research in this direction. 


\section{Giriş}

Tanınmış obua eğitmenlerinin yazdıkları metotlar incelendiğinde, kamış yapımı ile ilgili çeşitli tavsiyelere ve yorumlara yer verildiği görülmektedir.

'Paris Konservatuvarl'nda 1882'den 1919'a kadar ders veren ünlü pedagog ve obuacı Georges Gillet (1854-1920), ögrencilerine kamış yapımını ögretmek yerine onlara hazır kamış vermiş veya onları kendi yaptığ kamışların satıldı̆̆ı dükkânlara yönlendirmiştir. Daha sonra kendisinin ögrencisi ve aynı zamanda yeğeni olan Fernand Gillet (1882-1980) ise, bunun bir hata olduğunu belirtmiş, hazır kamış almaya alışan öğrencilerin, kendi başlarına kaldıklarında sorun yaşadıkları ve eğitmenlerine hazır kamış elde etme yönünden bağımlı kaldıkları tespitini yapmıştır” (Storch, 1977, s. 5).

François Joseph Garnier'in (1755-1825) “Methode raisonnee pour de haut-bois" adl metodu, obua için yazılmış en erken pedagojik materyallerden biri olma özelliğini taşımaktadır. Bu metotta, kamış materyalinin obua performansı ile olan özel ilişkisinden bahseden Garnier, kamışın önemini şu sözleriyle dile getirmektedir: "Hakkıyla konuşan kamış, obuanın kalbidir" (Garnier, 1800, s. 5).

En eski obua öğretmenlerinden biri olarak bilinen John Bannister (1624/5-1679) iyi bir kamışın çalışı ne kadar kolaylaştırabileceğini anlatmaktadır. "The Spritely Companion" adlı kitabında "Çalış, iyi bir kamışla bir flüt kadar kolay ve yumuşak olur" demektedir (Bannister, 1695, s. 20, 47).

Henri Brod (1799-1839), kamış yapımının tüm aşamalarının tarif edildiği "Methode pour le Hautbois" (1830) adlı obua metodunda, kamış yapımında kullanılan forma ve iç kazıma makineleri bile icat edilmeden önce, kargı seçiminden iyi ton elde etmenin yollarına kadar kamış yapımı ile ilgili tavsiyelerde bulunmuştur. Anlaşıldığı üzere, o zamanlar bile kargı seçiminin iyi bir kamış tonu elde edilmesinde etkili olduğu fark edilmiştir. Obua eğitmenleri, kamış yapım aşamalarını, bu aşamaların hangi koşullarda iyi sonuç verebileceğini, iyi ton elde etme yöntemlerini araştırmaya başlamışlar, metotlarında bu konuların önemine vurgu yapan tavsiyelerde bulunmuşlardır. Ayrıca Brod, obua metoduna şöyle yazmıştır:

"İhtiyacımız olan kamışların nasıl yapılacağını bilmek en önemli şeydir. Ĕger bu önemli nokta ihmal edilirse, yetenek ve çalışma tamamen yok olur. Öğretmenlerimizden isteyerek iyi kamış elde edebileceğimiz doğrudur, fakat kendi kendimize yapabilmek büyük bir avantajdır, çünkü kamıslar dudakların, dişlerin ve her bir bireyin alışkanlıklarına uyum sağlamak zorundadır. Bizden başka hiç kimse bizim performansımızın mükemmel olmasının bağlı olduğu bu kü- 
çük şartlart iyice hesaba katmaz. Eğer iyi araçlar ve iyi kalite kargıyla donanıml isek kamış üretimi çok da zor değildir. Sabır ve özenli bir titizlik ister. Bu iki özellik kısa sürede bizi tatminkâr sonuçlara götürecektir” (aktaran Şensöz, 2008, s. 314).

Ancak aynı kitabın 1947 basımında farklı bir görüşe rastlanmaktadır. "Kamış yapımı üzerine olan bölüm kitaptan çıkarılmıştır çünkü sıradan bir obuacı için kendi kendine kamış yapmak zor bir iştir, virtüöz için bir baş belasıdır ve bir bütün olarak ele alındığında bu zahmete değmez" (Şensöz, 2008, s. 314).

$\mathrm{Bu}$ ifade değişikliği birçok obuacı için yaptıkları çalışmalardan istedikleri sonucu elde edemedikleri zaman duydukları hayal kırıklığını göstermektedir. İhtiyacımız olan kamışların nasıl yapılacağını bilmek ve o kamışları elde edebilmek oldukça zor bir iştir. Kamışın doğası gereği hava şartlarına göre değişim gösteren dokusu, bireysel ağız, diş yapısına ve ton anlayışına uygun kamış yapma gerekliliği, bire bir aynı işlemleri uyguladığınızda bile farklı kamışlar elde etmenin getirdiği sonuçlara katlanmak zorunda olduğunuz gerçeğini değiştirmemektedir. Aynı şekilde yaptığınız bir kamış iyi sonuç verirken diğeri iyi bir performans göstermeyebilir. Bu da istedikleri gibi kamış elde edemeyen obuacılar için oldukça moral bozucu bir etkendir.

Obua kamışlarıyla ilgili duyduğu hayal kırıklığından rahatsızlığını dile getiren Amerikan ekolünün önemli temsilcilerinden biri olan ünlü obuacı Marcel Tabuteau'nun (18871966) serzenişi, bu duruma örnek olarak gösterilebilir. Kendisi öğrencilerine "Ben 45 yıldır obua çalıyorum, 44 yılım ise bu nankör enstrümanı bırakma arzusuyla geçti” demiştir (Storch ve Tabuteau, 2008, s. 239-240).

Önemli obua pedagoglarının da aktardığı bilgiler incelendiğinde obua icracısının kendi ağız yapısı ve üfleyiş biçimine göre kamış yapabilmesinin önemi oldukça açıktır. Ancak kusursuz bir performansın anahtarı anlatılan özellikte yani kişinin kendine uygun olan kamışı yapabilmesi ile doğrudan ilişkilidir. Bu yaklaşıma örnek olarak Apollon Rose Marie Barret‘ nin (1804-1879) yazdığı metodunda bir obuacının kendi kamışını yapabilmesinin öneminin aktardığı bölüm verilebilir: "Yorumcuların kendi kamışlarını kendilerinin yapması en önemli şeydir, kimse bir çalgıcının kendi ihtiyaçlarına göre yaptı̆̆ı kamışın bir başka çalgıcıya hiç uymaması durumunu yargılayamaz” (Barret, 1862, s. 10-11).

60'lı yılların ünlü obua sanatçısı David A. Ledet tarafından yazılan "Oboe Reed Styles” (1981) adlı kitabın ikinci kısmında dünyanın çeşitli ülkelerinden 79 obuacının kamışla- 
rının resimlerine, obuacıların özgeçmişlerine ve yaptıkları kamış stilleri hakkında yorumlara yer verilmiştir. Aynı zamanda Fransız, Alman, İngiliz ve Viyana kamış yapım stillerinin analizi ile ilgili çalışmalar yapan Ledet'in bu çalışması 70'li yılların en ünlü obuacılarının kamış stilleri hakkında bir doküman olma özelliğini taşımaktadır.

Yukarıda örnekleri verilen ünlü pedagogların görüşlerinden de anlaşılmaktadır ki kamış yapımı eğitimi, yani kişinin bireysel ağız pozisyonu ve ton anlayışına göre kamış yapabilme becerisinin öğrenciye kazandırılması, obua eğitiminin önemli bir parçasıdır. Aktarılan bilgiler göstermektedir ki yukarıdaki görüşlerine yer verilen eğitimcilerin ve yorumcuların kamış yapımına verdikleri önem aşikârdır. Ancak profesyonellerin bu görüşlerine rağmen, günümüz müzik okullarının müfredatlarına baktığımız zaman, kamış eğitimine yönelik bir dersin yer almadığını görmekteyiz. Ayrıca bu mesleği profesyonel olarak icra eden eğitmen ve yorumculara referans olabilecek kamış yapmayı öğretme stratejileri ile ilgili bir kaynağın olmadığı da tespit edilmiştir. Bu durumun nedenini ortaya çıkarabilmek için öncelikle obua ve kamış eğitimi alanında yapılan çalışmalara bakmak ve bu çalışmalarda değinilen sorun ve çözümleri ele almak gerekmektedir. Obua kamışı ile ilgili yapılan araştırmaların sınırlı sayıda olması çalışma sırasında karşılaşılan en büyük zorluklardan biri olmuştur. Bu nedenle çalışmanın günümüz obua icracılarına kaynak olması ve eğitim repertuvarı içerisine kamış yapım dersinin dahil edilmesi gerekliliğinin bu alandaki eksikliği tamamlaması hedeflenmektedir. Obua eğitiminde öğrencilerin kendi fiziksel yapılarına (diş, ağız, çene, dudak) göre kullanacakları kamışları başta finansal faktörler olmak üzere her açıdan kimseye muhtaç olmadan kendilerinin yapabilmesi amaçlanmalıdır. Ayrıca obua eğitiminin gelişim ve sürekliliği açısından, kamış eğitimi öğrencilerin motivasyonuna olumlu katkı sağlayarak başarılarını arttıracaktır. Unutulmaması gereken diğer bir husus, öğrencinin fiziksel durumuna uygun olmayan bir kamışın öğrenciyi obua eğitiminden soğutacağıdır. Obua ve obua kamışını bir bütün olarak kabul etmek gerekirse, kamış yapımı öğrenimi ile birlikte obua eğitimi tamamlanacak ve en önemlisi öğrencilerde özgüven açısından iyi bir tona sahip rahat çalabilecekleri bir kamış elde etmiş olmaları ayrıcalık hissi yaratacaktır.

\section{Yöntem}

Çalışmanın evrenini Yükseköğrenim Kurulu Başkanlığı Tez Merkezi ve Proquest veri tabanında obua kamışı üzerine yazılan tezler oluşturmaktadır. YÖK Tez Merkezi'nde obua ve obua kamışı belge başlığı altında yer alan 16 tezden sadece 3'ü kamış yapımına 
değinmiştir. Proquest veri tabanında "oboe" ve "oboereeds" belge başlığı altında yer alan 227 tezden 60 tanesi görüntülenememiştir. Bu belge başlıkları altında yer alan sadece 11 tez içerisinde kamış yapımına değinilmiştir. Yine aynı veri tabanında "oboe reedsmaking" belge başlığı altında yapılan taramada elde edilen biri yüksek lisans tezi olan toplam 12 tez seçilmiş, kamış yapımının ele alınmadığı tezler bu çalışmaya dahil edilmemiştir. Tezlere bulgular kısmında numara verilmiş ve daha sonra bu numaralar üzerinden değerlendirme yapılmıştır. Sonuç olarak toplam 15 tez bu çalışmanın örneklemini oluşturmaktadır.

\section{Bulgular}

Yükseköğrenim Kurulu Tez Merkezi'nde obua belge başlığı altında yapılan araştırmada elde edilen 16 tezden sadece üçünün kamış yapımına değindiği tespit edilmiştir.

1- Aybegüm Şekercioğlu “20. ve 21. yy’a ait obua eserlerinde yeni arayışlar ve çalım teknikleri” adlı tezinde 20.yy'dan günümüze kadar bestelenmiş eserlerde karşılaş1labilecek yeni çalış teknikleri hakkında bilgiler sunmuş ve çalışı kolaylaştıracak çalışma ve bilgilere yer vermiştir. Avant-garde müziğin gerektirdiği tınısal doku, geleneksel repertuvar için uygun olan kamışlardan daha farklı kamışlar kullanılması; ses kırılması, akor, hızlı artikülasyon ve diğer özel efektlerin yapılabilmesi için kamışların özel bir esneklikte olması gerektiği vurgulanmaktadır. "Genellikle Fransız ve Alman tarzında oyulmuş ve kazılmış kamışlar modern müzik için standart kabul edilmiştir çünkü bahsedilen gelişmiş teknikleri uygulayan çalgıcılar genellikle bu ekollerden gelmektedir. Amerikan tarzı kamışlar benzer efektleri her zaman çıkartamaz” tespiti yapılmıştır (Şekercioğlu, 2008, s. 36).

2-“Barok’tan Modern'e obuanın mekanik yapısının gelişimini inceleyen tezin kamış yapımı başlıkl1 4. bölümünde Ayşin Pelin Şensöz, kamışın neden çalgıcı tarafından yapılması gerektiğine, kamış, çalgı ve çalgıcının her birinin farklı bir tabiatı olduğuna değinmiştir. Üstelik bu üç elemanın fiziksel uyumu günden güne değişim gösterebilmektedir. Kamışın ağızdaki pozisyonu, şekli ve dudaklara karşı direnci, hava basıncının gücü, ağız boşluğunun şekli, dişlerin ve dilin fiziksel yapısının bireyden bireye farklılık gösterdiği, ses üretimini ve kalitesini etkilediği tespiti yapılmıştır. Bu tezde ayrıca kamış yapım aşamaları ile bilgi verilmiş, kargı seçiminden iyi bir ton elde etmenin yollarına kadar çeşitli tavsiyelerde bulunulmuştur (Şensöz, 2008, s. 313).

3-“Günümüz Obua Kamış Yapım Tekniklerinde Alman ve Amerikan Ekolleri Üzerine Bir Araştırma” başlıklı tezde Ece Erdem, temel kamış yapımı teknikleri başlı̆̆ı altında, 
kamış yapımında kullanılan tüm malzemeleri ve makineleri tanıtmış, kamış yapım aşamaları ile farklı ekoller hakkında bilgi vermiş, ulusal ve uluslararası obua sanatçıları ve obua eğitmenlerinin kamışlarını fotoğraflarla örneklemiş ve bazıları ile kamış yapımı biçimleri hakkında röportaj yapmış, bu alanda farklı bakış açıları sunmaya çalışmıştır. Bu tezde bu konunun önemi şu şekilde vurgulanmıştır:

"Profesyonel bir obua çalıcısının kendi kamışlarını şahsen yapmaması neredeyse imkânsızdır. Çünkü kişilerin dudak yapısı, dudak pozisyonu (kamışın ağız içinde nasıl kavrandığı), üfleyiş tekniği, diyaframın kullanış tekniği ve buna benzer kişisel özellikleri ile kullandığ kamışın yapısı birebir ilintilidir. Bu sebeple çok güzel bile olsa, eğer kamış kişinin fiziksel yapısına ya da üfleme alışkanlıklarına uygun değilse, iyi bir performans için uygun araç olmayabilir. Hazır kamıs satın almak için gerekli finansal koșullara sahip olunsa bile, bir kamış yapımcısının her çalıcıya uyacak bir kamış yapması imkânsız olduğu için, hazır kamış hiçbir zaman kişisel beklentilerimizi karşılayamaz" (Erdem, 2010, s. 4).

Proquest veri tabanında oboe, oboereeds ve reedsmaking belge başlı̆̆ altında kamış yapımına değinen 12 tez bulunmaktadır.

1- "Basic Preparation For Oboe Auditions By Using Selected Oboe Excerpts" adl1 tezin “Critical Factors Involving Reed Preparation” adlı bölümünde Shen Wang, kamıș seçiminin üç boyutu olduğundan bahsetmektedir: 1- Karg1 seçimi, 2- Amerikan stili bir kamışın yapım aşamasının öncelikli prensipleri ve 3- Performans sınavının amacına uygun kamış hazırlama sürecinde yer alan kritik faktörler. Çalışma, bir obuacının enstrüman çalışmak kadar iyi bir kamış hazırlamak için de yeterli zaman ayırması gerektiğine, bunun çalıcının kendine güvenli ve iyi hazırlanmış bir hisle sınava girerek fiziksel performansına olan pozitif etkisine, kamışın nasıl ve hangi koşullar altında seçilmesi gerektiği ile kamış yapım aşamalarının tarifine odaklanmaktadır (Wang, 2009, s. 82).

2- "Transitioning To The Oboe: Methods And Resources To Asisst In Switching To The Oboe From Other Woodwind Instruments" adl1 tezin "Transitioning To The Oboe" adl1 bölümünde Scott Richard Reese, kamış ve dudak pozisyonu ilişkisine, farklı dudak pozisyonlarına göre kamıștan nasıl titreșim elde edilebileceğine değinmiștir (Reese, 2012, s. 15-21). Ayrıca tezin obua kamışı adlı bölümünde kamış hakkında temel bilgilere, Fransız ve Amerikan kamış kazıma stillerinin tanıtımına, karşılaşılan entonasyon problemlerine ve kamışı temiz tutmanın önemine yer verilmiştir (Reese, 2012: 47-50). 
3- "The Oboe Manual A Handbook For Music Educators And School Oboists: Common Sense Information About The Oboe For Everyone Who Needs It" adl1 tezin "About Ree$d s$ ” adlı bölümünde Loyd Raymond Rathbun kamışın bir obuacı için önemine, kamış yapmak için ihtiyaç duyulan minimum ekipmana, kamış sarmaktan kazımaya tüm kamış yapım aşamalarının tarifine, kargı seçimine ve kamışları nasıl korumak gerektiğine değinmektedir (Rathbun, 1942, s. 29-45).

4- "Oboebasics.Com A Modern Method For Oboe Embouchure” adlı tezin sonuç k1smından sonra yer alan Ek-1 “About Reeds” başlığ1 altında Jennifer Elise Muehrcke, kamış yapımı ile ilgili başlangıç ve ileri seviye öğrencilerine farklı açılardan yaklaştığından bahsetmektedir. Öğrencileri için önemli olan noktaları belirleyip o konuları öğretmekte, başlangıç aşamasında olan obua öğrencilerine kendi yaptığg kamışları vermektedir. İlk olarak lise aşamasında iyi ton elde etmiş olan öğrencileri ile kamış yapımına başlamakta olduğundan ve kamış yapımı öğretimine obua eğitimi ile aynı zamanda başlamanın kamış yapımının zorluklarından dolayı öğrencilerin motivasyonunu olumsuz yönde etkilediğinden bahsetmektedir (Muehrcke, 2012, s. 134-135).

5- "The Development Of Contemporary Oboe Technique” adlı tezin Ek-A kismının 1. bölümünde yer alan “Remarks On The Reed” başlı̆̆1 altında Nora Post, kamış kalitesinin ve esnekliğinin modern müziği yorumlamaktaki önemine dikkat çekmektedir. "Yeni müziğin gerektirdiği dinamik farklılıklar ve artikülasyon çeşitliliğine cevap verebilecek nitelikte olan bir kamış ile bu eserleri hakkıyla yorumlamak mümkün olabilir" demektedir (Post, 1979, s. 148-149).

6- "A Guide To The Study Of The Classical Oboe” adlı tezin 3. bölümü, kamış ve kamış yapımına ayrılmıştır. Bu bölümde James Grush, 1800'lerden önce basılmış obua metotlarında, obua eğitmenlerinin kamış yapımı ile ilgili oldukça kayıtsız olduğundan bahsetmektedir ve kamış yapımı ile ilgili ilk bilgilere Garnier'in obua metodundan önce rastlanmadığına dikkat çekmektedir. Bu tezden öğrenildiğine göre, yine 1800'lü yıllardan önce tek başına kamış yapımının gelişmiş ve uygulanan bir tekniği bulunmamaktadır. Kamış yapımının önemi, 18. yy.'dan itibaren belli kriterler geliştirmeyi başaran ve metotlarında bazı ölçüler veren pedagoglar sayesinde dikkat çekmeye başlamıştır. Garnier “Methode raisonnee pour le hautbois" (1800) adlı metodunda, kamış yapımına eğitimsel açıdan yaklaşmış, kendi yaptığı kamışların resimlerle ölçülerini yayımlamış, kamış yapım aşamalarını madde madde sıralamış, öğrencilerine enstrümanı kontrol etme aşa- 
masına gelinceye kadar rahat kamışlar kullanmaları tavsiyesinde bulunmuştur. Bu gelişme, 19. yy.'dan itibaren obua pedagoglarının metotlarında hiç değilse nasıl kamış yaptıklarına dair bazı örneklere yer vermelerini sağlamış, her dudak pozisyonunun farklı kamışlar gerektirdiği sonucuna varmalarına sebep olmuştur. Ancak Amand Vanderhagen metodunda (1790), her obuacının kendi üfleyiş pozisyonuna göre birbirinden farklı kamışlar yaptığını belirtmekte, obua ile ilgili her şeyin iyi bir kamışa bağlı olduğuna değinmekte ama kamış yapımının yazılı bir anlatımı olamayacağı görüşünü bildirmektedir (Grush, 1972, s. 16-22, 26).

7- "The Development And Continued Evolution Of The American Style Of Oboe Playing " adlı tezin ikinci bölümünde Rebecka Elizabeth Rose, çift kamışlı enstrüman çalanların, sürekli değişken bir malzemeyle kamış yapmaları gerektiğinden dolayı bakır enstrümanlara göre büyük zorluklar yaşadıklarından bahsetmekte, ünlü obua pedagogu Tabuteau'nun kendine özgü kamış kazıma biçimiyle, o zamana kadar kullanılan tüm Avrupa standartlarını değiştirdiğinden ve şu anda Amerika'da da kabul edilmiş olan ve halen kullanılmakta olan bir teknik geliştirdiğinden bahsetmektedir. Yine tanınmış Amerikalı obua pedagogu David A. Ledet, “Oboe Reed Styles Theory and Practice” (1981) adlı kitabında tüm dünyadan ünlü obuacıların nasıl kamış kazıdıklarına dair örnekler vermiştir. Bu kitap belirli bir ton anlayışına sahip obuacıların nasıl bir formda kamış yaptıklarını görmek ve taklit etmek açısından bulunmaz bir kaynaktır. Ledet ayrıca bu kitapta, Fransız, Amerikan, İngiliz, Alman ve Viyana stili kamış kazıma biçimlerini resimlemiştir. Arizona State Üniversitesi obua profesörü Schuring, "Oboe Art and Method" adlı kitabında (2009) kamış yapımının tüm aşamaları hakkında detay vermektedir. Schuring kamış yapmaya yeni başlayanlara "Siz kamış yapmıyorsunuz, kamış yapmayı öğreniyorsunuz bu ikisi arasında büyük fark var” demektedir (aktaran Rose, 2017, s. 21). $\mathrm{Bu}$ çalışmada Rose sonuç olarak, profesyonel olan çok başarılı obuacıların bile kamış yapımında zorluk yaşadıklarından bahsetmekte, ton kalitesinin en önemli unsuru olan mükemmel bir kamış elde etme çabasının obuacılar için asla bitmeyeceğini vurgulamaktadır (Rose, 2017, s. 19-22).

8- "The Philadelphia Influence On The Art Of Reedmaking" adlı tezin özet kısmında Reid G. Messich, ünlü obua pedagogu Leon Goossens'ten bir alıntı yapmaktadır. Goossens, her obuacının dolayısıyla her obuacının kullandığı kamışın tamamen kendine has ve özgün olması sebebiyle hiçbir zaman iki obuacının aynı enstrüman ve aynı kamışı kullansalar bile birbirinin aynı ses rengini elde edemeyeceğini söylemektedir (Goossens 
ve Roxburgh, 1977, s. 31). Messich, kamış yapmayı öğrenmenin özellikle başlangıç aşamalarında oldukça stres yarattığından dolayı bu sürecin her obuacı için özel bir çaba gerektirdiğinden bahsetmekte, kamış yapımı hakkında ne kadar çok şey bilinirse mükemmel kamış diye bir şey olmamasına rağmen o kadar başarılı olunacağına inanmaktadır. Bir obuacı için kamış yapmanın amacının, enstrümancının performans esnasında kendine özgü kalitelerini ortaya çıkarmak olduğunu vurgulamaktadır. Messich bu çalışmada Philadelphia'da kullanılan kamış yapım stilini ve sürecini anlatarak, bu stil bilgilerinin ışığında obua öğrencilerine ve profesyonel obuacılara yardımcı olabilecek farklı bir bakış açısı sunmayı amaçlamıştır (Messich, 2012, s. 1-2).

9- "A Technical Comparison Of An 1807, A 1916, And A 1968 Oboe And Related Reedmaking And Performance Problems " adl1 tezde David Leroy Busch, 1807, 1916 ve 1968 y1llarında kullanılan obualar için uygun olduğunu düşündüğü kamışların ölçülerine değinmekte ve bu kamışları hem birbirleriyle hem de günümüz kamışları ile karşılaştırmaktadır. Bu tezde her bir kamışın farklı bir formu ve kazıma stili olduğundan bahsedilmektedir. Tüm bu materyallere ait fotoğraflar örnek olarak sunulmuştur (Busch, 1972, s. $1-10,16-30)$.

10- "Teaching The Double Reeds A Practical Approach To The Teaching Of Oboe And Basson In The Schools" başlıklı tezin "The Reed" problem adlı kamış problemi başlıklı IV. bölümünde William Burgess Smith, bütün obuacıların hedefinin kendi kamışlarını yapabilmek olması gerektiğini söylemektedir. Smith, obua çalmaya yeni başlayan öğrencilere uygun kamışlar sağlamanın eğitmenlerin sorumluluğunda olduğunu belirtmekte, ancak kamış yapımı hakkında bilgi vermeye enstrüman eğitimi ile aynı zamanda başlanması gerektiğini vurgulamaktadır. Smith'e göre, bu çok arzu edilen bir yol olmasa da her obuacı önce kendisine temin edilen kamışlarla kamış yapımı hakkında ön bilgi elde etmekte, daha sonra kendi kendine deneyerek zaman içerisinde kamış yapmayı öğrenmektedir. "Her obuacı kendisine ve müziğin gerektirdiği her duruma uygun performans sergileyebilen kamışları kendisi yapabilme becerisine sahip olmalıdır. Bu özellikleri başka hiç kimsenin yaptığı kamışlar tatmin edici şekilde karşılayamaz" demektedir (Smith, 1953, s. 45-46).

11- "Oboereed-Making Pedagogy In The United States: A Survey" adlı tez Amerika'da kamış yapım tarihi, stilleri ve metotları hakkında kapsamlı bir araştırma yapmış, kamış yapım malzemelerini tanıtmış, Amerika'da lisans düzeyinde eğitim veren obuacılara ka- 
mış yapımını nasıl öğrettikleri ile ilgili bir anket düzenlemiştir. Elisabeth Ann Rennick tarafından yapılan ve bu alanda yapılmış en kapsamlı çalışma özelliği taşıyan araştırma, 2009 yılında Amerika ve Kanada' da 4 yıllık eğitim veren ve müzik alanında lisans diploma programı içeren müzik fakülteleri ve üniversitelerin müzik bölümlerinde tam zamanlı olarak görev yapan obua eğitmenlerine e-posta yoluyla yöneltilen 74 sorudan oluşan bir anket sonuçlarından yola çıkarak, Amerika'da yaygın olarak uygulanan kamış yapım metotlarını belirlemeyi amaçlayan bir çalışmadır. E-posta yoluyla 273 kişiye sorular gönderilmiş bunlardan 115 eğitmen (\%42) ankete katılmıştır. Anket, katılımcıların nasıl kamış yaptıkları ve kamış yapmayı nasıl öğrettiklerine cevap arar niteliktedir. Araştırmada çoğunlukla Amerika'da uygulanan kamış yapımı eğitimi metotlarını keşfetmek için birçok soru sorulmuş, bölüm bölüm bu sorulardan örnekler verilmiştir. Ancak tez, ankette sorulan tüm soruları kapsamamaktadır (Rennick, 2010, s. 1-4, 6-42).

12- "Significant Learning Principles as Reedmaking” adlı tezde Jessica Warren, kamış yapımının çoğunlukla haftalık obua derslerinde öğretildiğinden, ancak enstrüman dersinin teknik ve repertuvar çalışmasından arta kalan kısa bir sürede kamış yapımı ile ilgilenildiğinden bahsetmektedir. Kamış yapımının masterclass ortamlarında da ele alınmasına rağmen nadiren eğitim kurumlarında kredili bir ders olarak önerildiğinin de altını çizmektedir. Warren, kamış yapımı ile ilgili kaynakların daha çok uygulayıcı yani yorumcular için yazıldığı ve içerik olarak pedagojik olmaktan ziyade kamış yapımının teknik kısmına değinme eğiliminde oldukları tespitinde bulunmuştur. Kamış yapım pedagojisinin tarihsel boyutuna dikkat çeken Warren, Henri Brod'un "Methode pour le Hautbois" (yaklaşık olarak 1830) adlı metodundan önce kamış yapımı ile ilgili bilgi ve yapım aşamalarına obua metotlarında rastlanmadığından bahsetmektedir. 19. yy'dan başlayarak, kamış yapımını tarif eden, ölçüler veren hatta değişik ülkelerin kamış yapım stillerinden kapsamlı olarak bahseden kamış yapım kitapları basılmıştır. Ancak bu tezde Warren, kamış yapımı pedagojisi ile ilgili eğitmenlere hitap edebilecek, obua eğitmenlerinin konuyla ilgili yaşadıkları kaygıları giderebilecek öğretme stratejileri ve öğrenme aşamasının farklı seviyeleri ile ilgili yol gösterici bir kaynağın olmadığı tespitinde bulunmuştur (Warren, 2017, s. 1-3, 8, 15).

Görülmektedir ki Türkiye'de obua ile ilgili yazılmış 16 tezden içerisinde kamış faktörünün önemine değinen üç tez bulunmaktadır. Bunlardan ilkinde Aybegüm Şekercioğlu 20. ve 21. yy eserlerini incelerken, bu eserlerin gerektirdiği dinamikleri gösterebilmek için mümkün olduğu kadar esnek ve yumuşak kamışlarla yorumlamak gerektiğine; "Ba- 
rok'tan modern'e obuanın mekanik yapısının gelişimi” ni incelerken Ayşin Pelin Şensöz, kamışın neden çalgıcı tarafından yapılması gerektiğine, çünkü kamışın iyi bir ton elde etme yolunda en önemli faktör olduğuna; üçüncü tez olan "Günümüz obua kamış yapım tekniklerinde Alman ve Amerikan ekolleri üzerine bir araştırma" başlığı altında Ece Erdem, kamış yapımında kullanılan tüm malzemeler ve makineleri tanıtmaya, kamış yapım aşamaları ile farklı ekoller hakkında bilgi vermeye, ulusal ve uluslararası obua sanatçıları ve obua eğitmenlerinin kamışlarını fotoğraflarla örneklemeye, obua sanatçıları ile yaptığı röportajlara yer vermeye çalışmıştır.

Proquest veri tabanında yer alan 12 tezden sadece 6 tanesi obua kamış yapımı eğitiminin önemine değinmektedir. 1, 2 ve 3 numaralı tezler, bir obuacının enstrüman çalışmak kadar iyi bir kamış hazırlamak için de yeterli zaman ayırması gerektiğine, kamış ve dudak pozisyonu ilişkisine, kamış yapımı hakkında temel bilgilere ve kamış yapım aşamalarına; 5 numaralı tez, modern müziği yorumlamak için nasıl kamışlar kullanmak gerektiğine; 8 numaralı tez, Amerika'nın Philadelphia şehrinde kullanılan özgün kamış yapım şeklinin her aşamasının anlatımına; 9 numaralı tez, 1807, 1916 ve 1968 yıllarında kullanılan kamış yapım stillerinin karşılaştııılmasına yer vermektedir. Kamış yapımı öğrenimine vurgu yapanların içerisinden 4 numaralı olan tezde Muehrcke, kamış yapımı ile ilgili başlangıç ve ileri seviye öğrencilerine farklı açılardan yaklaştığından bahsetmektedir. Kendi tecrübelerine dayanarak hangi seviyeye gelmiş bir öğrencinin kamış yapmaya başlaması gerektiği hakkında tavsiyelerde bulunmaktadır. Ancak spesifik rakamlar vermemekte, örneklerini başlangıç aşaması, lise aşaması olarak adlandırmaktadır. 6 numaralı tezde Grush, 1800'lerden önce basılmış obua metotlarında, obua eğitmenlerinin kamış yapımı ile ilgili oldukça kayıtsız olduğundan bahsetmektedir ve nasıl kamış yapıldığı ile ilgili ilk bilgilere Garnier'in obua metodundan önce rastlanmadığına dikkat çekmektedir. 7 numaralı tezde Rose, kamışlı enstrüman çalanların bakır nefesli enstrüman çalanlara oranla yaşadıkları zorluklara, Tabuteau ve Ledet gibi pedagogların kendilerinin ve tüm dünyadan ünlü obuacıların nasıl kamış yaptıkları ile ilgili ölçü ve resimlere metotlarında yer verdiklerine, bu metodun o dönem için kamış yapmayı öğrenmek adına bulunmaz bir kaynak olduğuna değinmekte iyi bir obua tonu kalitesinin en önemli unsuru olan mükemmel bir kamış elde etme çabasının obuacılar için asla bitmeyeceği tespitinde bulunmaktadır. 10 numaralı tezde Smith de tüm obuacıların hedeflerinin kendi kamışlarını yapmak olması gerektiğinden bahsetmekte, bunu başarana kadar ise öğrencilerine rahat çalabilecekleri kamışlar sağlamanın eğitmenlerin sorumluluğunda olduğu 
vurgusunu yapmaktadır. 11 numaralı tez bu alanda yapılan en detaylı çalışma özelliğini taşımaktadır. Bu tezde Rennick, Amerika'da obua eğitimi veren kurumlarda kamış yapımının hangi sıklıkta, nasıl ve hangi araç gereçlerle öğretildiğini sorgulamaktadır. 12 numaralı tezde ise Warren, kamış yapımının eğitim kurumlarında nadiren kredili ders olarak önerildiğinin altını çizmektedir. Kamış yapımı ile ilgili kaynakların daha çok uygulayıcı yani yorumcular için yazıldığı ve içerik olarak pedagojik olmaktan ziyade kamış yapımının teknik kısmına değinme eğiliminde olduklarına vurgu yapıp kamış yapımı pedagojisi ile ilgili eğitmenlere hitap edebilecek, öğretme stratejileri ve öğrenme aşamasının seviyeleri ile ilgili yol gösterici bir kaynağın olmadığı tespitinde bulunmuştur.

Özellikle 11 numaralı "Oboereed- making pedagogy in the United States: A survey" adl1 tezde uygulanan anket sonuçları kamış yapımı öğretiminin her kurumda çok farklı uygulandığını tespit etmiştir. Ayrıca her eğitim kurumunda kamış yapımı için gerekli olan aletler bulunmamaktadır. Eğitmenlerin kamış yapım biçimi birbirlerine göre farklılık göstermektedir

Öğretme metotları sezgiseldir ve belli bir müfredat izlememektedir. Ayrıca araştırmada kamış yapımının iyi bir ton elde etmenin tartışmasız tek koşulu olduğu vurgulanmaktadır. Birçok makine sayesinde hazır kamış imal edilse de çalıcıların kendilerine göre elde yaptıkları kamışlar profesyonel eğitmenler ve öğrenciler tarafından her zaman tercih edilmektedir. Obua çalgısının tarihi boyunca kamışların nasıl yapıldığı ve yapılış biçimleri çoğunlukla eğitmenler ile yorumcular arsında sözlü olarak paylaşılmıştır. İşin ilginç yanı bu gelenek kendisini bilimsel çalışmalardan daha yaratıı bir şekilde geliştirebilmiştir. Kamış yapımının bazı temel kuralları zaman içerisinde gelişme gösterse de en büyük gelişme kamış yapımı stillerinde yaşanmıştır. Fransız, Alman ve Amerikan kamış yapım ekolleri oluşmuştur.

Zamanla çalıcılar, imal edilmiş her türlü kamış yapımı malzemesine ulaşma imkânına sahip olmuştur. Ancak kamış yapım stilleri ve kamış yapmayı öğretme metotları yazılı bir dokümana dönüşememiş, bir müfredat oluşturulamamıştır. Bu araştırmanın sonucu göstermektedir ki kamış yapımı biçimleri ve öğretme stilleri arasında birçok farklılıklar bulunmakta ve iyi kamış yapmak için tek ve doğru bir kamış yapım şekli bulunmamaktadır.

Anket çalışmasındaki cevaplar da bizi şu sonuca götürmüştür: Eğitim yöntemleri eğit- 
menler, öğrenciler ve kurumlara göre değişkenlik göstermektedir. Öğrencilerin ne zaman kamış yapmaya başlamaları gerektiği ve ne zaman eğitmenlerinden bağımsız kamış yapabilmeyi başaracakları belirsizdir. Kamış yapımı eğitimi süreçleri belgelenmemiştir. Kamış yapım dersi obua dersinin içerisinde verilmekte, öğrencinin seviyesi, yeteneği veya ihtiyacına göre kamış yapımı eğitimine ayrılan süre değişmektedir.

\section{Sonuç ve Tartışma}

Sonuç olarak kamış yapımının konservatuvarların ders kataloglarında ayrı bir ders olarak yer alması ve bu dersin sistemli bir müfredatının oluşturulması gerekmektedir. Obua eğitmenlerine yönelik, kamış yapımını ne zaman ve nasıl öğrettikleri ile ilgili bir anket çalışması yapılabilir, öğrencilerin hangi aşamada ve ne tür problemlerle karşılaştıkları tespit edilebilir. Bu sayede başlangıç aşamasından bireysel kamış yapımına kadar nasıl bir metot oluşturulabileceği ve hangi sınıfta hangi konuların öğretileceği saptanabilir.

Her öğrenciye uygun kamış yapım stilini belirlemek fiziksel yapı ile doğrudan ilintilidir. Eğitmenlerin hedefi, öğrencilerinin yumuşak ve esnek bir ton ile rahat çalabilecekleri kamışlar yapabilmesi olmalıdır. Başlangıç olarak kamış yapım malzemeleri ve yapım aşamaları tanıtılmalı, daha sonra kamış yapım biçimleri öğretilmeli ve bu biçimler uygulamalı olarak denenmelidir. Her yapım aşaması olgunlaştıktan sonra bir diğer aşamaya geçilmelidir. Her öğrencinin el becerisi aynı oranda olmayabilir. Başlangıç aşamasında kamış yapımının getirdiği zorluklar öğrencilerin motivasyonunu kırabilir. Kamış yapımı öğreniminin uzun bir sürece dayandığı ve her obua çalan kişinin bu aşamadan geçmek zorunda olduğu hatırlatılmalıdır.

Obua çalgısında dinleyici, enstrümandan çıkan ses rengini önemser. Çalıcılar da herkes tarafından beğenilecek bir ses rengi elde etmeyi amaçlamaktadır. Ton anlayışına uygun ses rengi elde edebilmek enstrüman seçimi, doğru nefes kullanımı ve kişiye uygun kamış yapabilmekten geçer. Ancak sadece ses rengine odaklanmamak, rahat çalış ve geniş bir dinamik yelpazesine sahip esnek çalışı da önemsemek gerekir.

Bunun için kamış yapımı eğitimine mümkün olduğunca erken başlamak gereklidir. Eğitim sürecinde kamış yapım çalıştayları düzenlenebilir ve farklı kurumlardaki öğrencilerin kamış yapım biçimlerini tanıması ve diğer öğrenciler ile fikir alışverişinde bulunmaları sağlanabilir. Ayrıca eğitmenler, enstrüman dersinde kamıştan kaynaklanan problemleri geçiştirmemeli, öğrencinin sorunu teşhis etmesini ve uygulayarak çözmesini 
sağlamalıdır. Başarılı bir obua performansı kamış yapımında en iyiyi aramaktan vazgeçmemeye bağlıdır.

Not: Bu makalede yer alan sonuçların bir kısmı 3-5 Mayıs 2018 tarihlerinde Alanya Alâeddin Keykubat Üniversitesi’nde gerçekleşen 4. Uluslararası Güzel Sanatlar Sempozyumu'nda sözlü bildiri olarak sunulmuştur

\section{Kaynakça}

Barret, A. M.-R. (1862). A complete method for the oboe. Londra: Jullien \& Co.

Berman, M. (1988). The art of oboe reedmaking. Toronto: Canadian Scholar's Press.

Busch, D. L. (1972). A technical comparison of an 1807, a 1916, and a 1968 oboe and related reedmaking and performance problems (Doktora tezi). ProQuest Dissertations and Theses veri tabanından erişildi. (UMI No. 7313695)

Erdem, E. (2010). Günümüz obua kamış yapım tekniklerinde Alman ve Amerikan ekolleri üzerine bir araştırma, (Yayınlanmamış Yüksek Lisans Tezi). Dokuz Eylül Üniversitesi Güzel Sanatlar Enstitüsü, İzmir

Garnier, F. J. (1800). Méthode raisonné epour de haut-bois. Paris, Pleyel

Garnier, F. J. (1803). Methode. Paris, L'imprimeriedu Conservatoire de Musique.

Goossens L. ve Roxburg E. (1977). Oboe. New York, NY: Schirmer Books A Division of Macmillian Publishing Co., Inc.

Grush, J. (1972). A Guide to the study of the classical oboe (Doktora tezi). ProQuest Dissertations and Theses veri tabanından erişildi. (UMI No. 7225121)

Ledet, D. A. (1981). Oboe reed styles theory and practice. Bloomington:

Indiana University Press.

Messich, R. G. (2012). The Philadelphia influence on the art of reedmaking (Doktora tezi). ProQuest Dissertations and Theses veri tabanından erişildi. (UMI No. 3551227)

Muehrcke, E. (2012). Oboebasics.com a modern method for oboe embouchure (Doktora tezi). ProQuest Dissertations and Theses veri tabanından erişildi. (UMI No. 3521693)

Nora, P. (1979). The development of contemporary oboe technique (Doktora tezi). ProQuest Dissertations and Theses veri tabanından erişildi. (UMI No. 7918862)

Rathbun, R. L. (1942). The oboe manual. A handbook for music educators and school oboists: Common sense information about the oboe for everyone who needs it (Doktora tezi). ProQuest Dissertations and Theses veri tabanından erişildi. (UMI No. EP67601)

Reese, R. S. (2012). Transitioning to the oboe: Methods and resources to asisst in switching to the oboe from other woodwind instruments (Doktora tezi). ProQuest Dissertations and Theses veri tabanından erişildi. (UMI No. 1520878)

Rennick, E. A. (2010). Oboereed-making pedagogy in the United States: A survey (Doktora tezi). ProQuest Dissertations and Theses veri tabanından erişildi. (UMI No. 3409862)

Rose, R. E. (2017). The development and continued evolution of the American style of oboeplaying (Doktora tezi). ProQuest Dissertations and Theses veri tabanından erişildi. (UMI No. 10623780)

Schuring, M. (2009). Oboe art and method. London:Oxford University Press. 
Smith, W. B. (1953). Teaching the double reeds a practical approach to the teaching of oboe and basson in the schools (Doktora tezi). ProQuest Dissertations and Theses veri tabanından erişildi. (UMI No. EP47685.)

Storch L. (1977). Georges Gillet: Master performer and teacher. Journal of the International Double Reed Society 6.

Storch, L. ve Tabuteau, M. (2008). How do you expect to play the oboe if you can 't peel mushroom?. Bloomington: Indiana University Press.

Şekercioğlu, A. (2008). 20. ve 21. yy'a ait obua eserlerinde yeni arayışlar ve çalım teknikleri (Yayınlanmamış Yüksek Lisans Tezi). İstanbul Üniversitesi Sosyal Bilimler Enstitüsü, İstanbul.

Şensöz, A. P. (2008) Barok'tan modern'e obuanın mekanik yapısının gelişimi (Yayınlanmamış Sanatta Yeterlik Tezi). İstanbul Üniversitesi Sosyal Bilimler Enstitüsü, İstanbul.

Vanderhagen, A. (1790). Methode nouvelle et raisonnee pour le hautbois. Paris: Boyer.

Wang, S. (2009). Basic preparation for oboe auditions by using selected oboe excerpts (Doktora tezi). ProQuest Dissertations and Theses veri tabanından erişildi. (UMI No.3392677)

Warren, J. (2017). Significant learning principles as reedmaking pedagogy (Doktora tezi). ProQuest Dissertations and Theses veri tabanından erişildi. (UMI No.10278588) 
